Headquarters: 3400 International Drive, NW, Washington, D.C., 20008-3006, USA.

Website: http://www.itso.int

Director-General: Ahmed Toumi (Morocco).

\section{International Trade Union Confederation (ITUC)}

Origin. Founded in Nov. 2006, the ITUC was formed after the merging of the International Confederation of Free Trade Unions (ICFTU) and the World Confederation of Labour (WCL). The WCL was established in 1920 as the International Federation of Christian Trade Unions, but went briefly out of existence in 1940 owing to the suppression of affiliated unions by the Nazi and Fascist regimes. Declining to merge with the World Federation of Trade Unions (WFTU) or ICFTU, it reconstituted in 1945 and became the WCL in 1968. The founding congress of the ICFTU took place in London in Dec. 1949 following the withdrawal of some Western trade unions from the WFTU, which had come under Communist control.

By Feb. 2009 the ITUC represented 168m. members of 311 affiliates in 155 countries and territories, consisting of the former affiliates of the WCL and ICFTU and a number of other national organizations.

Aims. The ITUC aims to defend and promote the rights of workers, particularly the right to union organization and collective bargaining; to combat discrimination at work and in society; to ensure that social concerns are put at the centre of global economic, trade and finance policies; to support young people's rights at work; and to promote the involvement of women in trade unions. In 2006 it also ran campaigns against child labour and to promote the prevention of HIV/AIDS.

Organization. The Congress meets every four years to set policies and to elect the General Secretary and the General Council, composed of 70 members, which is the main decision-making body between congresses. The President and Deputy Presidents are appointed by the General Council. The Founding Congress was held in Vienna in Nov. 2006.

The ITUC has offices which deal with the International Labour Organization (Geneva), the United Nations (New York) and the World Bank and International Monetary Fund (Washington, D.C.). There are also offices in Amman, Moscow, Sarajevo and Vilnius. The ITUC is a member of the Global Unions Council and the Trade Union Advisory Committee to the OECD.

Headquarters: Bd du Roi Albert II, N55, bte 1, Brussels 1210, Belgium.

Website: http://www.ituc-csi.org

General Secretary: Guy Ryder (UK).

President: Sharan Burrow (Australia).

\section{International Tribunal for the Law of the Sea (ITLOS)}

The International Tribunal for the Law of the Sea (ITLOS), founded in Oct. 1996 and based in Hamburg, adjudicates on disputes relating to the interpretation and application of the United Nations Convention on the Law of the Sea. The Convention gives the Tribunal jurisdiction to resolve a variety of international law of the sea disputes such as the delimitation of maritime zones, fisheries, navigation and the protection of the marine environment. Its Seabed Disputes Chamber has compulsory jurisdiction to resolve disputes amongst States, the International Seabed Authority, companies and private individuals, arising out of the exploitation of the deep seabed. The Tribunal also has compulsory jurisdiction in certain instances to protect the rights of parties to a dispute or to prevent serious harm to the marine environment, and over the prompt release of arrested vessels and their crews upon the deposit of a security. The jurisdiction of the Tribunal also extends to all matters specifically provided for in any other agreement which confers jurisdiction on the Tribunal. The Tribunal is composed of 21 judges, elected by signatories from five world regional blocs: five each from Africa and Asia; four from Western Europe and other States; four from Latin America and the Caribbean; and three from Eastern Europe. The judges serve a term of nine years, with one third of the judges' terms expiring every three years.

Headquarters: Am Internationalen Seegerichtshof 1, D-22609

Hamburg, Germany.

Website: http://www.itlos.org

Registrar: Philippe Gautier (Belgium).

\section{International Union Against Cancer (UICC)}

Founded in 1933, the UICC is an international non-governmental association of 331 member organizations in 104 countries.

Objectives. The UICC is the only non-governmental organization dedicated exclusively to the global control of cancer. Its objectives are to advance scientific and medical knowledge in research, diagnosis, treatment and prevention of cancer, and to promote all other aspects of the campaign against cancer throughout the world. Particular emphasis is placed on professional and public education.

Membership. The UICC is made up of voluntary cancer leagues, patient organizations, associations and societies as well as cancer research and treatment centres and, in some countries, ministries of health.

Activities. The UICC creates and carries out programmes around the world in collaboration with several hundred volunteer experts, most of whom are professionally active in UICC member organizations. It promotes co-operation between cancer organizations, researchers, scientists, health professionals and cancer experts, with a focus in four key areas: building and enhancing cancer control capacity, tobacco control, population-based cancer prevention and control, and transfer of cancer knowledge and dissemination. The next UICC World Cancer Congress is scheduled to take place in Beijing in 2010.

Address: 62 route de Frontenex, 1207 Geneva, Switzerland.

Website: http://www.uicc.org

President: Franco Cavalli (Switzerland).

Executive Director: Isabel Mortara (Switzerland). 